ISAHP Article: A Style Guide for Paper Proposals To Be Submitted to the International Symposium of the Analytic Hierarchy Process 2016, London, U.K.

\title{
ANALYSIS OF THE SAUDI NATIONAL TRANSFORMATION PROGRAM/ ANP APPLICATION
}

In October 2015, Saudi Council for Economic and Development Affairs proposed the National Transformation Project (NTP) 2020 in response to drop in price of oil to around US \$ 26; which threw the country into an unexpected deficit of $\$ 100$ billion. The NTP focusing on the key drivers for economic growth. Although only outline of the NTP is released, we know the problem is very complex as it involves numerous actors, and many entangled criteria and elements. Knowing that the government is taking a developmental approach that is inclusive, transparent and accountable to all stakeholders in society. Hence, we opted to implement the Analytic Network Process. The ANP is a sound methodology for structuring the problem to find which policy to focus on to make the transformation as effective as possible taking into account social and political factors in addition to economic ones.

Keywords: Analytic Network Process, Economic Transform, strategic planning, Saudi Arabia.

\section{Introduction}

Saudi Arabia is known for patronizing its citizens taking country from a primitive society to a state that is the envy of the world in terms of development.

The sudden drop in price of oil recently slumped the country into an unexpected deficit of $\$ 100$ billion. . This indebtedness might grow to $50 \%$ if oil price does not rebound and/or Saudi Arabia does not create other sources of revenue to balance its budget. It has two alternative courses of action to take; to either freeze all future and in-process infrastructure and cut expenses to bare bone and maintain patronage of its citizens; or, start on transforming the economy to by getting the private sector to contribute more towards the country's GDP. Furthermore, Saudi Arabia is suffering of inefficient bureaucratic system that one could argue that managerial reform is necessary before fiscal reform or privatization. Each approach comes with its benefits opportunities, costs and risks. This paper will evaluate the impact of NTP using the ANP analysis to prioritize these alternatives from the perspectives of benefits, costs, opportunities and risks. This analysis will add value to government's endeavor in its transformation effort by assisting the decision makers on what aspects to focus on to improve the rate of success of the transformation. We will demonstrate the ANP methodology as a very helpful tool towards the government developmental approach based on transparency and involving all stakeholders.

\section{Literature Review}

The "resource curse" is a phenomenon describing countries whose economy depends heavily on exporting natural resources. (Cendrero,2014). Saudi Arabia is one among many such as Netherlands, Nigeria etc. The effort to depart from relying on exporting oil has been the main goal through all Saudi economic plans since its first one in 1970. However, success in achieving this goal is far from being satisfactory. Figures show that Saudi Arabia is still depending heavily on oil exports. In 2015, 90\% of government revenue was from oil. Jim Krane (2015) reflects the gradual change in Saudi Arabia from "swing producer" to supplier of refined oil products. To diversify from overdependence on oil is not a Saudi unique issue, (AL Bassam ,2015). Also, a similar and related study by Kashcheeva and KevinK (2015) threw light on the changes of the oil industry that 
ISAHP Article: A Style Guide for Paper Proposals To Be Submitted to the International Symposium on the Analytic Hierarchy Process 2016, London, U.K.

could play a role in how the NTP could be used. Among countries who underwent economic transformation is Malaysia. The Malaysia's economic transformation plan 2020 has been implemented through the private sector, (Naira, et.al, 2014).

Our objective is to find out what is the best alternative to achieve the NTP goal using the ANP methodology; not used in previous related studies on transformation

\section{Hypotheses/Objectives}

The objectives of this work are twofold; first, to implement the analytic network process to analyze the (NTP) which the Saudi Government is embarking on developing. Our BOCR model will speculate its social, economic and political impact from all stakeholders point of view and prioritize the different policies for implementing the NTP. The second objective is to emphasize the importance of using systematic methodology, such the ANP (Saaty,1996), for complex decisions making.

\section{Research Design/Methodology}

To develop the model a deep related literature and governmental reports were examined. A pool of experts; international and locals( with academic or experience back ground)were interviewed to answer four basic questions exploring the most expected economic, political and social benefits, opportunities, costs and risks respectively. The common points were extracted from these interviews were used to design the ANP model.

The analysis is intended to find out how such factors will contribute to the long term strategic criteria the government is committed to achieve via its successive development plans (2004-2020). These main criteria are international competitiveness, social wellbeing, and sustainability. The stakeholders are the business sector, householders and the public sector. The results is to priorities four alternatives suggested: fiscal reform, managerial reform, privatization, and status quo. The judgments are gathered through successive meetings with experts in finance, economics, and sociology and operations management. CI ratio was addressed by reviewing judgments wherever it exceeds $10 \%$.

\section{Data/Model Analysis}

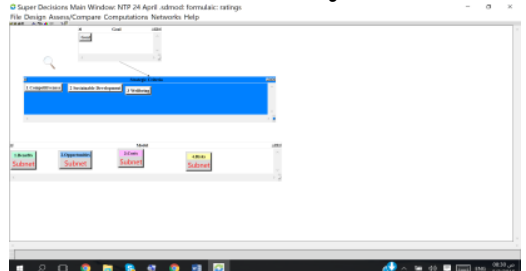

Figure 1: toplevel network for the NTP model

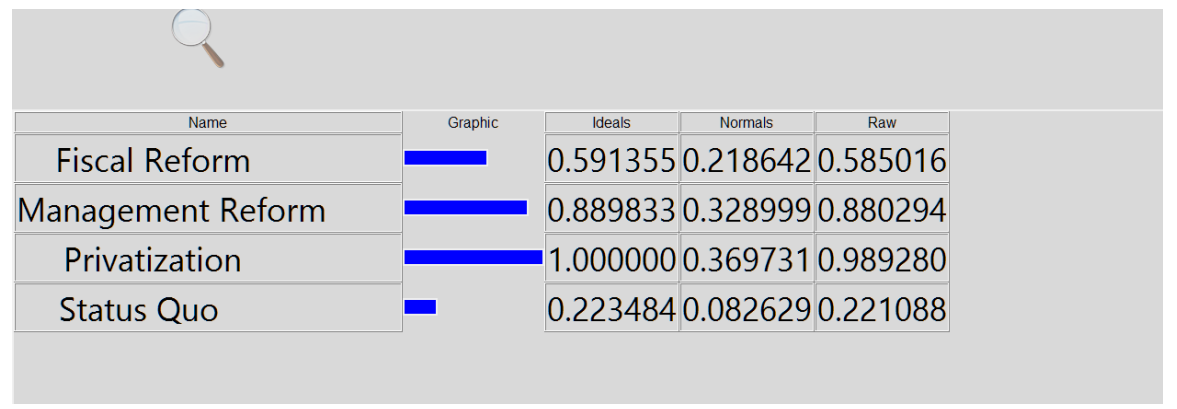

Figure 2: Synthesizing the alternatives from the network subnet under benefits 
ISAHP Article: A Style Guide for Paper Proposals To Be Submitted to the International Symposium on the Analytic Hierarchy Process 2016, London, U.K.

\section{Limitations}

This study in particular requires a lot of courage to address. Since details of the NTP is not made public, authors are faced by reluctance of experts to participate in the interviews or later on in the judgments. Not to mention the ambiguity of responses received and not daring to be critical on such bold plan and platform. However, being persistent, we hope to finalize the study in due time based on expertise judgments.

\section{Conclusions}

Since the study is yet to be completed, we are not ready to share results. It is hoped by August results should be ready and our paper will be updated before the conference date.

\section{Key References}

Albassam, B. (2015). Economic diversification in Saudi Arabia: Myth or reality?

Resources Policy, Volume 44, March, 112-117.

Jim Krane (2015). Saudi Arabia's role in global energy markets is changing. ... Read "A Refined Approach: Saudi Arabia Moves Beyond Crude," http://bakerinstitute.org/research/saudi-arabia-moves-beyond-crude-oil/Mar 23, 2015.

Juan M. Ramírez Cendrero (2014) Has Bolivia's 2006-12 gas policy been useful to combat the resource curse?. Resources Policy, Volume 41, September, 113-123

Mila Kashcheeva, Kevin K.Tsui (2015) Political oil import diversification by financial and commercial traders. Energy Policy, Volume 82, July, 289-297.

Ministry of Planning and Economy. Long-term strategy for the Saudi economy. 2005.

Nair,V, Lo May Chiun, Sanjit Singh(2014). The international tourists' perspective on Malaysia's EconomicTransformation Programme (ETP), Procedia - Social and Behavioral Sciences 144, 433 - 445 